Egyptian Journal of Aquatic Biology \& Fisheries

Zoology Department, Faculty of Science,

Ain Shams University, Cairo, Egypt.

ISSN $1110-6131$

Vol. 25(5): 541 - 552 (2021)

www.ejabf.journals.ekb.eg

\title{
Effect of Heavy Metals Contamination on Biochemical Parameters of the Nile Tilapia from Different Fish Farms
}

\section{Hala Elshahat Ghannam ${ }^{1}{ }^{*}$, Ghada Taha Belal ${ }^{1}$, Ghada Salah Abdelaziz ${ }^{2}$, Soha Mohamed Hamdy ${ }^{3}$}

${ }^{1}$ Pollution Laboratory, Freshwater and Lakes Division, National Institute of Oceanography and Fisheries, Cairo, Egypt.

${ }^{2}$ Chemistry Laboratory, Freshwater and Lakes Division, National Institute of Oceanography and Fisheries, Cairo, Egypt.

${ }^{3}$ Chemistry Department, Faculty of Science, Fayoum University, Fayoum, Egypt.

Corresponding Author: drhalaghannam@yahoo.com

ARTICLE INFO

Article History:

Received: Oct. 5, 2021

Accepted: Oct. 19, 2021

Online: Oct. 30, 2021

Keywords:

Nile tilapia,

heavy metals,

fish farm,

biochemical parameters
ABSTRACT

This study is concerned with the contamination of heavy metals and its effect on biochemical parameters and enzyme activity of the Nile tilapia collected from three fish farm. For this reason the physical and chemical parameters of farms water were examined. Also, heavy metals $(\mathrm{Zn}, \mathrm{Cd}, \mathrm{Pb}$, $\mathrm{Fe}$, and $\mathrm{Cu}$ ) were measured in water, fish blood, and sediment collected from the farms under study. The results of $\mathrm{pH}$ in the three farms EL-Galini, Locanda, and EL-Bats were 7.95, 8.03, and 8.06, respectively where, dissolved oxygen were 5.9, 7.2, and $6.0(\mathrm{mg} / \mathrm{l})$. The values of heavy metals in water showed relative variation $\mathrm{Fe}>\mathrm{Zn}>\mathrm{Cu}>\mathrm{Pb}>\mathrm{Cd}$ in all three different farms. For sediment EL Galini farm have the highest value for all the examined heavy metals followed by Locanda and EL-Bats farm. The results showed a significant increase in levels of (Random blood sugar), and (Alkaline Phosphatase) with $P$-value $0.004,0.002$ respectively in both Locanda and EL-Bats farms when compared with EL Galini farm. Also, there was a significant decrease in levels of creatinine, (Creatinine Kinase) and (Aspartate Transferase) with P-value 0.02 and 0.05 for creatinine, $<0.001$ and $<0.001$ for CK and $<0.001$ and $<0.001$ for AST, respectively in both Locanda and EL-Bats farms when compared with EL Galini farm.

\section{INTRODUCTION}

Water is very important for fish and its quality is one of the main factor in pond management until it affects fish production. The quality of water generally means the water parameter which must be present for optimum growth of aquatic organisms (Ehiagbonare and Ogundiran, 2010). Water quality is made up of physical, chemical and biological factors which effect on the use of water for fish farming purposes. These factors include dissolved oxygen, $\mathrm{pH}$, temperature, and electrical conductivity. Aquaculture, a rapidly expanding business in the Asia-Pacific 
since 90s, has been an important source of food security and employment in many countries (Stanley, et al., 2003). Tilapia (O. niloticus) is a widely-cultured species in the ponds of the country, fish productivity depends on the physicochemical characteristics of the water body. The environmental impact of aquaculture is observed in many ways including user conflicts, change of ecosystems and water pollution, of these possible negative impacts, water pollution of water resources is the most common complaint and has attracted the greatest attention through the nations (Cripps and Bergheim, 2000). The quality of water of any aquatic ecosystem arises by the interaction of physical chemical and biological component of the habitat. Aquatic biota presents in any aquatic ecosystem directly influence the physicochemical characteristics of that aquatic ecosystem. The physicochemical parameters have important significance in determining the trophic status of aquatic habitats (Sharma, et al., 2009). Between aquatic organisms, fish cannot escape from the toxic effects of these pollutants, and are generally considered to be the most organisms for pollution monitoring in aquatic ecosystems (Beyer and Vermeulen, 2003). So, fish samples can be considered as one of the most important indicators in freshwater systems for the respect of metal pollution rate (Rashed, 2001). The commercial and edible species have been studied in order to check for those harmful to human health, while blood is a path physiological reverse of the all body parts, and therefore, blood parameters are important in investigation the structural and functional state of fish insecure to toxicants (Begüm, et al., 2005). Changes in the biochemical blood parameters indicate changes in metabolism and biochemical processes of the organism, resulting from the impacts of various pollutants, and they make it possible to study the mechanisms of the impacts of these pollutants (Adhikari, et al., 2004).

So the aim of this work was the detection of different heavy metals in water, fish blood, and sediment collected from different farms (EL Gilani, Locanda and EL Bats farms) at El-Fayoum Government. Also the study investigate the effect of heavy metals on biochemical parameters and some enzyme activity offish collected from the three farms under study.

\section{MATERIALS AND METHODS}

This study was carried out in Shakshouk Fish Research Station, EL-Fayoum Governorate, National Institute of Oceanography and Fisheries, Egypt.

\section{Collection and analysis of Water and Fish samples}

Water samples were collected from three different commercial farms (EL Gilani, Locanda and EL Bats farms, respectively). The physical and chemical parameters and heavy metals in water samples were determined according to APHA (1998). Sediment samples were dried at $80^{\circ} \mathrm{C}$ in oven and grinding to fine particles, $1.0 \mathrm{~g}$ of fine grinded samples was digested according to Kouadia and Trefry (1987) method. Heavy metal 
determination $(\mathrm{Fe}, \mathrm{Pb}, \mathrm{Zn}, \mathrm{Cu}$ and $\mathrm{Cd})$ in water and sediment samples were detected using atomic absorption (Perkin Elmer 3110 USA) with graphite atomizerHGA-600.

Fish samples Nile tilapia (Oreochromis niloticus) were collected from the same three commercial farms with weight (170-230 g) and length (20- $25 \mathrm{~cm})$. Heavy metals in fish blood were detected according to Barley and She (2013) by inductively coupled plasma mass spectrometry (ICP-MS) at Soil and Water Laboratory, Faculty of Agriculture, Fayoum University.

\section{Collection and analysis of blood samples}

Blood samples were collected in eppendorf tubes from the caudal vein of Oreochromis niloticus then collected samples centrifuged at $3000 \mathrm{rpm}$ for 15 minutes and the supernatant serum obtained by using micropipette and stored at $4^{\circ} \mathrm{C}$ till determination of urea, creatinine, AST (Aspartate Transferase), ALT (Alanine Trasferase), (RBS) Random Blood Sugar, creatinine kinase (CK), alkaline phosphatase (ALP), and heavy metals (cadmium, zinc, iron, lead and copper). Urea, creatinine, ALT and AST level was carried out by a kit supplied by BioSystems, (Barcelona, Spain). (RBS) Random Blood Sugar was recorded according to Trinder (1969) using kit purchased from (Randox Laboratories, UK). ALP was carried out according to Tietz, et al., (1983). CK was carried out by UV kinetic method.

\section{Statistical analysis}

The data were analyzed by one-way ANOVA and significant differences were determined by Duncan Waller Multiple Range Test at 5\% level using SPSS Statistical Package Program SPSS (2008).

\section{RESULTS AND DISCUSSION}

\section{Physical and chemical parameters of waters from three different farms}

The results of physical parameters in the three different farms water recorded in Table (1). The data recorded that there was non-significant variation at the level of $\mathrm{pH}$ and temperature of Locanda and EL-Bats farms when compared with EL-Galini farm. But, there was a significant decrease of total dissolved solids in Locanda and EL-Bats farms with $P$-value (0.002 and 0.005 , respectively) when compared with EL-Galini farm and $P^{*}$-value (0.006) when compared with locanda farm.

Water temperature influences the onset of fish spawn, aquatic vegetation growth, and the biological demand for oxygen in ponds. The increases in temperature lead to decrease in oxygen, which give harmful effect on fish life and in some cases lead to fish death (Ghannam, 2021). Fish can become stressed in water with a $\mathrm{pH}$ ranging from 4.0 to 6.5 and 9.0 to 11.0 (Stevens, 2009). 
Table (1). Physical parameters of water collected from three different fish farms.

\begin{tabular}{|l|c|c|c|c|}
\hline \multicolumn{1}{|c|}{ Parameters } & Groups & EL-Bats Farm & Locanda Farm & EL-Galini Farm \\
\hline $\mathrm{pH}$ & Range & $7.8-8.1$ & $7.9-8.1$ & $8.0-8.2$ \\
& Means \pm SD & $7.95 \pm 0.22$ & $8.03 \pm 0.18$ & $8.06 \pm 0.85$ \\
& P-value & & 0.76 & 0.62 \\
& P*-value & & & 0.83 \\
\hline Temperature $\left({ }^{\circ} \mathrm{C}\right)$ & Range & $31-33$ & $31-33$ & $31-32$ \\
& Means \pm SD & $32 \pm 1.4$ & $32 \pm 0.70$ & $31 \pm 2.1$ \\
& P-value & & 0.7 & 0.8 \\
& P*-value & & & 0.6 \\
\hline TDS $(\mathrm{mg} / \mathrm{l})$ & Range & $47.0-47.12$ & $11.0-11.21$ & $11.2-11.7$ \\
& Means \pm SD & $47.06 \pm 0.08$ & $11.20 \pm 0.28$ & $11.36 \pm 0.51$ \\
& P-value & & 0.002 & 0.005 \\
& P*-value & & & 0.06 \\
\hline
\end{tabular}

-Data are represented as means \pm SD of 3 farms. $\boldsymbol{P}$-value:-when different groups compared with EL-Gilini Farm, $\boldsymbol{P} *$-value: - when different groups compared with Locanda Farm, SD: standard deviation $\quad \mathbf{p}>0.05$ is non- significant $\quad \mathbf{p} \leq 0.05$ is significant

The present study showed that the mean of $\mathrm{pH}$ in the three farms EL-Galini, Locanda, and EL-Bats were 7.95, 8.03, and 8.06, respectively; this indicates that the water of the three farms are suitable for fish. Chemical parameters at Table (2) recorded that, the results of ammonia, ammonia un-ionized nitrate, nitrite, and dissolved oxygen were nonsignificant in Locanda and EL-Bats farms when compared with EL-Galini farm.

But there was a significant decrease of levels of salinity and organic matter in Locanda and EL-Bats farms with P-value 0.01 and 0.02, respectively, when compared with EL-Galini farm, $P^{*}$-value $(0.01)$ when compared with locanda farm. Also, our results detected significant increase levels of total alkalinity in Locanda farm and nonsignificant variation in EL-Bats farm when compared with EL-Galini farm.

Nitrogen compounds have been known as major metabolic products in fish farming, where nitrite may reach toxic concentrations in high density aquaculture systems and in flowing waters due to industrial pollution and agricultural wastes like fertilizer (Collins, 1975). Also, our results detected a significant increase of total alkalinity in Locanda farm when compared with EL-Galini farm however, it was detected non-significant variation in EL-Bats farm when compared with EL-Galini farm. Abubakar (2012) and Coldebella et al. (2017) recorded that alkalinity ranged $24.8 \mathrm{mg} / \mathrm{l}$ to $48 \mathrm{mg} / \mathrm{l}$ was suitable for fresh water fish culture. Salinity detected a significant decrease of levels of salinity in Locanda and EL-Bats farms with $P$-value (0.01) when compared with EL-Galini farm. Zaghloul (2008) showed deterioration in water quality of samples collected from the studied drainage canals (El-Bats and El-Wadi). Our study concerned with determination of organic matter in farms water in Locanda and EL-Bats farms with $P$-value (0.02) when compared with EL-Galini farm addition to dissolved oxygen value was observed nonsignificant in Locanda and EL-Bats farms when compared with EL-Galini farm. The results of dissolved oxygen in the three fish farms under study were 5.9, 7.2, and 6.0 for EL-Galini, Locanda, and EL-Bats farms, respectively. Talab et al. (2016) found that 
there are many parameter effect on dissolved oxygen content like temperature, $\mathrm{pH}$, and photosynthesis activity.

Table (2). Chemical parameters in water collected from three different fish farms.

\begin{tabular}{|c|c|c|c|c|}
\hline Parameters & Groups & EL-Bats Farm & Locanda Farm & EL-Galini Farm \\
\hline Ammonia (mg/l) & $\begin{array}{c}\text { Range } \\
\text { Means } \pm \text { SD } \\
P \text {-value } \\
P^{*} \text {-value } \\
\end{array}$ & $\begin{array}{c}0.357-0.425 \\
0.391 \pm 0.05\end{array}$ & $\begin{array}{c}0.256-0.325 \\
0.290 \pm 0.05 \\
0.10\end{array}$ & $\begin{array}{c}0.551-0.671 \\
0.611 \pm 0.08 \\
0.1 \\
0.07 \\
\end{array}$ \\
\hline $\begin{array}{l}\text { Ammonia Un- } \\
\text { ionized } \\
(\mathrm{mg} / \mathrm{l})\end{array}$ & $\begin{array}{c}\text { Range } \\
\text { Means } \pm \text { SD } \\
P \text {-value } \\
P^{*} \text {-value } \\
\end{array}$ & $\begin{array}{c}0.034-0.046 \\
0.04 \pm 0.01\end{array}$ & $\begin{array}{c}0.043-0.063 \\
0.053 \pm 0.01 \\
0.4\end{array}$ & $\begin{array}{c}0.06-0.082 \\
0.200 \pm 0.02 \\
0.3 \\
0.5 \\
\end{array}$ \\
\hline $\begin{array}{l}\text { Total } \\
\text { Alkalinity(mg/l) }\end{array}$ & $\begin{array}{c}\text { Range } \\
\text { Means } \pm \text { SD } \\
P \text {-value } \\
P^{*} \text {-value }\end{array}$ & $\begin{array}{l}280-300 \\
90 \pm 14.1\end{array}$ & $\begin{array}{c}140-145 \\
145 \pm 7.0 \\
0.02\end{array}$ & $\begin{array}{c}280-300 \\
294 \pm 14.1 \\
1.00 \\
0.02\end{array}$ \\
\hline Salinity (g/l) & $\begin{array}{c}\text { Range } \\
\text { Means } \pm \text { SD } \\
P \text {-value } \\
P^{*} \text {-value } \\
\end{array}$ & $\begin{array}{c}8-9 \\
8.5 \pm 0.7\end{array}$ & $\begin{array}{c}1-1 \\
0.77 \pm 0.3 \\
0.01\end{array}$ & $\begin{array}{c}1-1 \\
0.75 \pm 0.3 \\
0.02 \\
1.00 \\
\end{array}$ \\
\hline $\begin{array}{l}\text { Organic matter } \\
(\mathrm{mg} / \mathrm{l})\end{array}$ & $\begin{array}{c}\text { Range } \\
\text { Means } \pm \text { SD } \\
P \text {-value } \\
P^{*} \text {-value } \\
\end{array}$ & $\begin{array}{c}21.00-21.36 \\
21.18 \pm 0.3\end{array}$ & $\begin{array}{c}7.32-7.6 \\
7.33 \pm 0.4 \\
0.003\end{array}$ & $\begin{array}{c}3.0-3.72 \\
3.38 \pm 0.5 \\
0.003 \\
0.02\end{array}$ \\
\hline $\begin{array}{l}\text { Nitrate } \\
(\mathrm{mg} / \mathrm{l})\end{array}$ & $\begin{array}{c}\text { Range } \\
\text { Means } \pm \text { SD } \\
P \text {-value } \\
P * \text {-value } \\
\end{array}$ & $\begin{array}{l}0.122-0.158 \\
0.141 \pm 0.02\end{array}$ & $\begin{array}{c}0.105-0.116 \\
0.110 \pm 0.01 \\
0.3\end{array}$ & $\begin{array}{c}0.182-0.218 \\
0.200 \pm 0.03 \\
0.1 \\
0.1 \\
\end{array}$ \\
\hline Nitrite (mg/l) & $\begin{array}{c}\text { Range } \\
\text { Means } \pm \text { SD } \\
P \text {-value } \\
P^{*} \text {-value } \\
\end{array}$ & $\begin{array}{c}4.211-5.312 \\
4.766 \pm 0.76\end{array}$ & $\begin{array}{c}5.024-6.214 \\
5.619 \pm 0.84 \\
0.4\end{array}$ & $\begin{array}{c}8.205-9.306 \\
8.755 \pm 0.78 \\
0.04 \\
0.06\end{array}$ \\
\hline $\begin{array}{l}\text { Dissolved } \\
\text { oxygen }(\mathrm{mg} / \mathrm{l})\end{array}$ & $\begin{array}{c}\text { Range } \\
\text { Means } \pm \text { SD } \\
P \text {-value } \\
P^{*} \text {-value }\end{array}$ & $\begin{array}{l}5.6-6.2 \\
5.9 \pm 0.4\end{array}$ & $\begin{array}{c}6.7-7.8 \\
7.2 \pm 0.7 \\
0.2\end{array}$ & $\begin{array}{c}5.7-6.3 \\
6.0 \pm 0.4 \\
0.8 \\
0.2\end{array}$ \\
\hline
\end{tabular}

-Data are represented as means \pm SD of 3 farms. $\boldsymbol{P}$-value:-when different groups compared with EL-Gilini Farm, $\boldsymbol{P} *$-value: - when different groups compared with Locanda Farm, SD: standard deviation $\quad \mathbf{p}>0.05$ is non- significant $\quad \mathbf{p} \leq 0.05$ is significant

\section{Heavy metals contaminated in water from three different fish farms}

As shown in Fig. (1), there is a significant decrease of $\mathrm{Zn}$ and Fe in Locanda and ELBats farms with $P$-value 0.001 and 0.001 for $\mathrm{Zn}$ and $<0.001$ and $<0.001$ for $\mathrm{Fe}$,

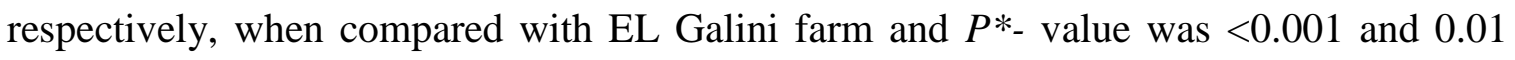
when compared with Locanda farm. But, there was a significant increase of $\mathrm{Cu}$ in ELBats farms with $P$-value 0.004 and $P^{*}$ - value 0.001 when compared with Locanda farm, and it was recorded non-significant variation in Locanda farm when compared with EL Galini farm. On other hand, there was non-significant change of $\mathrm{Cd}$ and $\mathrm{Pb}$ in both Locanda and EL-Bats when compared with EL Galini farm. 

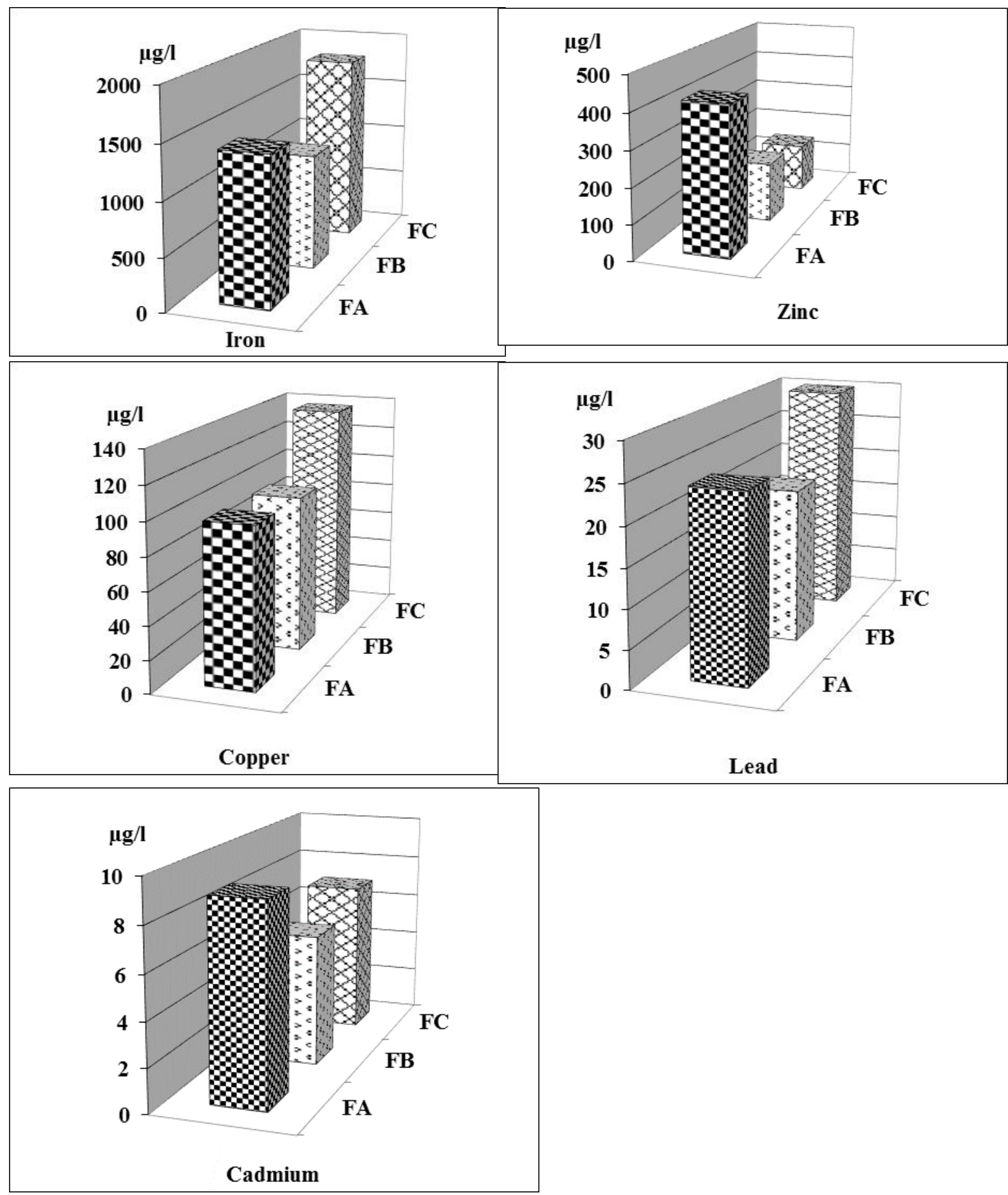

FA:-El- Gilani farm $\quad$ FB:-Locanda farm $\quad$ FC:- EL-Bats farm

Fig (1). Heavy metal concentrations $(\mu \mathrm{g} / \mathrm{l})$ in water collected from three different fish farms

The obtained results for heavy metals in water showed relative variation $\mathrm{Fe}>\mathrm{Zn}>$ $\mathrm{Cu}>\mathrm{Pb}>\mathrm{Cd}$ in all three different farms. Ali and AbdEl-satar (2005) studied the distribution patterns of heavy metals $(\mathrm{Fe}, \mathrm{Mn}, \mathrm{Zn}, \mathrm{Cu}, \mathrm{Pb}$, and $\mathrm{Cd}$ ) for water in some fish 
farms in EL-Fayoum (Goda1, 2; EL-Shoura and Shalakany). The allowed concentration of $\mathrm{Fe}, \mathrm{Pb}, \mathrm{Mn}$, and $\mathrm{Cu}$ were $0.3,0.01,0.1$, and $2.0 \mathrm{mg} / \mathrm{L}$, respectively according to WHO, (2011) and Egyptian Drinking Water Quality Standards (2007). The results of all metals in the three farms did not exceed the allowed limits. The higher concentrations of Mn may be related to the release of manganese from dead aquatic plants that become easy due to the decrease in water level with settling in water current beside the dissolution of sediment manganese and its presence water (Ghannam, et al., 2014). The increase in $\mathrm{Cu}$ values may be related to the high evaporation rate and elevation in temperatures of air and water or the release of copper from sediment to surrounding water (Warren and Zimmerman, 1994).

\section{Heavy metals contaminated in sediment from three different fish farms}

The results of accumulation of different heavy metals in sediment of the three fish farms were found at Table (3). There were a significant decrease in levels of $\mathrm{Zn}, \mathrm{Cu}$, and Fe in both Locanda and EL-Bats farms with $P$-value 0.004 and 0.002 for $\mathrm{Zn}, 0.005$ and 0.006 for $\mathrm{Cu}$, and 0.001 and $<0.001$ for $\mathrm{Fe}$, respectively, when compared with EL Galini farm, and $P^{*}$-value was $0.009,0.01$, and 0.002 when compared with Locanda farm. Also, $\mathrm{Pb}$ recorded low value in both Locanda and EL-Bats farms when compared with EL Galini farm, but Cd detected high value in Locanda farm when compared with EL Galini farm and EL-Bats farm.

Table (3). Accumulation of some heavy metals in sediment of three different farms

\begin{tabular}{|l|c|c|c|c|}
\hline \multicolumn{1}{|c|}{ Heavy metals } & Groups & $\begin{array}{c}\text { EL-Galini } \\
\text { Farm }\end{array}$ & $\begin{array}{c}\text { Locanda } \\
\text { Farm }\end{array}$ & $\begin{array}{c}\text { EL-Bats } \\
\text { Farm }\end{array}$ \\
\hline Zinc $(\mathrm{mg} / \mathrm{kg})$ & Range & $82.48-83.96$ & $75.4-76.12$ & $52.0-52.08$ \\
& Means \pm SD & $83.2 \pm 1.0$ & $75.7 \pm 0.5$ & $52.04 \pm 0.05$ \\
& $p$-value & & 0.004 & 0.002 \\
& $P^{*}$-value & & & 0.009 \\
\hline Copper $(\mathrm{mg} / \mathrm{kg})$ & Range & $33.84-43.56$ & $20.56-28.76$ & $7.56-11.68$ \\
& Means \pm SD & $38.7 \pm 6.8$ & $24.6 \pm 5.7$ & $9.6 \pm 2.9$ \\
& $p$-value & & 0.1 & 0.01 \\
& $P^{*}$-value & & & 0.01 \\
\hline Iron $(\mathrm{mg} / \mathrm{kg})$ & Range & $45040-45080$ & $36760-36920$ & $12249-12276$ \\
& Means \pm SD & $45060 \pm 28.3$ & $36840 \pm 113.3$ & $12262.5 \pm 19.0$ \\
& $p$-value & & 0.03 & $<0.001$ \\
& $P *$-value & & & 0.002 \\
\hline Lead $(\mathrm{mg} / \mathrm{kg})$ & Range & $7.0-7.0$ & $6.0-6.0$ & $6.0-6.0$ \\
& Means \pm SD & $7.0 \pm 0.0$ & $6.0 \pm 0.0$ & $5.1 \pm 0.0$ \\
\hline Cadmium $(\mathrm{mg} / \mathrm{kg})$ & Range & $0.12-0.12$ & $0.16-0.16$ & $0.04-0.04$ \\
& Means \pm SD & $0.12 \pm 0.0$ & $0.16 \pm 0.0$ & $0.04 \pm 0.0$ \\
\hline
\end{tabular}

-Data are represented as means \pm SD of 3 farms. P-value: - when different groups compared with ELGalini farm. $\boldsymbol{P}^{*}$-value: - when different groups compared with Locanda farm. $\mathbf{P}>\mathbf{0 . 0 5}$ is non- significant $\mathrm{p}$ $\leq \mathbf{0 . 0 5}$ is significant $\mathbf{S D}$ : standard deviation

It is clear from Table (3) that EL Galini farm have the highest value for all the examined heavy metals followed by Locanda farm and the lowest value were recorded in 
EL-Bats farm. The presence of organic matter in sediments is a source of nutrients for the living fauna and consider as important factor in the accumulation and release of pollutants in the water (Ahmed and Elaa, 2003). The high values of organic matter in the sediments might be related to the flourishing of phyto and zooplankton, which lead to high organic productivity (Boyd and Tucker, 1979).

\section{Accumulation of heavy metals in fish blood of three different farms}

The concentration of different heavy metals in blood of Nile tilapia fish from different fish farm were found in Table (4). The order of metal distribution in EL-Galini farm was $\mathrm{Zn}>\mathrm{Fe}>\mathrm{Cu}$ and the same order was obtained in Locanda farm, while in EL-Bats farms the order was $\mathrm{Zn}>\mathrm{Cu}>\mathrm{Fe}$. But, neither $\mathrm{Cd}$ nor $\mathrm{Pb}$ was detected in fish blood at the three different farms under study.

Zinc is an essential heavy metal for living organisms where the cells contain $\mathrm{Zn}$ as one of the essential components of various enzymes. It is involved in different aspects of cellular metabolism (Osredkar and Sustar, 2011). It is also necessary for a healthy immune system, cell division, synthesis of protein and collagen etc. (Yirgu, 2011). However, a higher amount of $\mathrm{Zn}$ have a toxic effect on human health (WHO, 2011). Copper is also an essential heavy metal and an important constituent of a living organism. It plays an important role in the production of hemoglobin, myelin, melanin, and it also helps in the normal functioning of the thyroid gland. As this mineral is present in many functions of the body, copper deficiency can produce an extensive range of symptoms like hernias, aneurysms, blood vessel breakage manifesting as bruising or nose bleeds (Yirgu, 2011).

Table (4). Heavy metals concentrations of Nile Tilapia fish blood in three different farms:-

\begin{tabular}{|l|c|c|c|c|}
\hline \multicolumn{1}{|c|}{ Heavy metals } & Groups & EL-Galini Farm & Locanda Farm & EL-Bats Farm \\
\hline Zinc & Range & $365.0-365.9$ & $562.7-563.1$ & $514.7-515.0$ \\
$(\mathrm{mg} / \mathrm{dl})$ & Means \pm SD $p$-value & $3365.45 \pm 0.64$ & $562.90 \pm 0.28$ & $514.89 \pm 0.16$ \\
& $P^{*}$-value & & $<0.001$ & 0.001 \\
& & & & $<0.001$ \\
\hline Copper & Range & $104.5-105$ & $90-90.2$ & $159-159.9$ \\
$(\mathrm{mg} / \mathrm{dl})$ & Means \pm SD $p$-value & $104.75 \pm 0.35$ & $90.10 \pm 0.14$ & $159.45 \pm 0.64$ \\
& $P^{*}$-value & & 0.01 & 0.001 \\
& & & & 0.003 \\
\hline Iron & Range & $201-203$ & $233.5-234$ & $157-157.6$ \\
$(\mathrm{mg} / \mathrm{dl})$ & Mean \pm SD $p$-value & $203.00 \pm 2.83$ & $233.80 \pm 0.42$ & $157.30 \pm 0.42$ \\
& $P^{*}$-value & & 0.04 & 0.001 \\
& & & & $<0.001$ \\
\hline
\end{tabular}

-Data are represented as means \pm SD of 3 farms. P-value :- when different groups compared with ELGalini farm. $\quad \boldsymbol{P}^{*}$-value:-when different groups compared with Locanda farm. $\mathrm{p}>0.05$ is non- significant $\mathrm{p} \leq 0.05$ is significant $\mathrm{SD}$ : standard deviation 


\section{Biochemical and enzyme parameters in blood of Nile tilapia fish}

Figs. $(2,3)$ show a significant increase of levels of RBS (Random blood sugar) and ALP (Alkaline Phosphatase)with $P$-value 0.004 and 0.002 for RBS (Random blood sugar) and 0.01 and 0.001 for ALP, respectively in both Locanda and EL-Bats farms when compared with EL Galini farm, and $P^{*}$-value was 0.002 and 0.001 when compared with Locanda farm. Also, there was a significant decrease in levels of creatinine, CK (Creatinine Kinase) and AST (Aspartate Transferase) with P-value 0.02 and 0.05 for creatinine, $<0.001$ and $<0.001$ for CK and $<0.001$ and $<0.001$ for AST, respectively in both Locanda and EL-Bats farms when compared with EL Galini farm; $P^{*}$-value was $<0.001$ when compared with Locanda farm. On other hand, there was a significant decrease in levels of urea in Locanda farm $(P$-value: $<0.001)$, but a significant increase ( $P$-value: 0.04$)$ in EL-Bats farm when compared with EL Galini farm, and $P^{*}$-value was 0.03 when compared with Locanda farm. Our results detected a significant increase of ALT in Locanda farm ( $P$-value: 0.01$)$, but a significant decrease $(P$-value: 0.01$)$ in ELBats farm when compared with EL Galini farm, and $P^{*}$-value was 0.002 when compared with Locanda farm. .
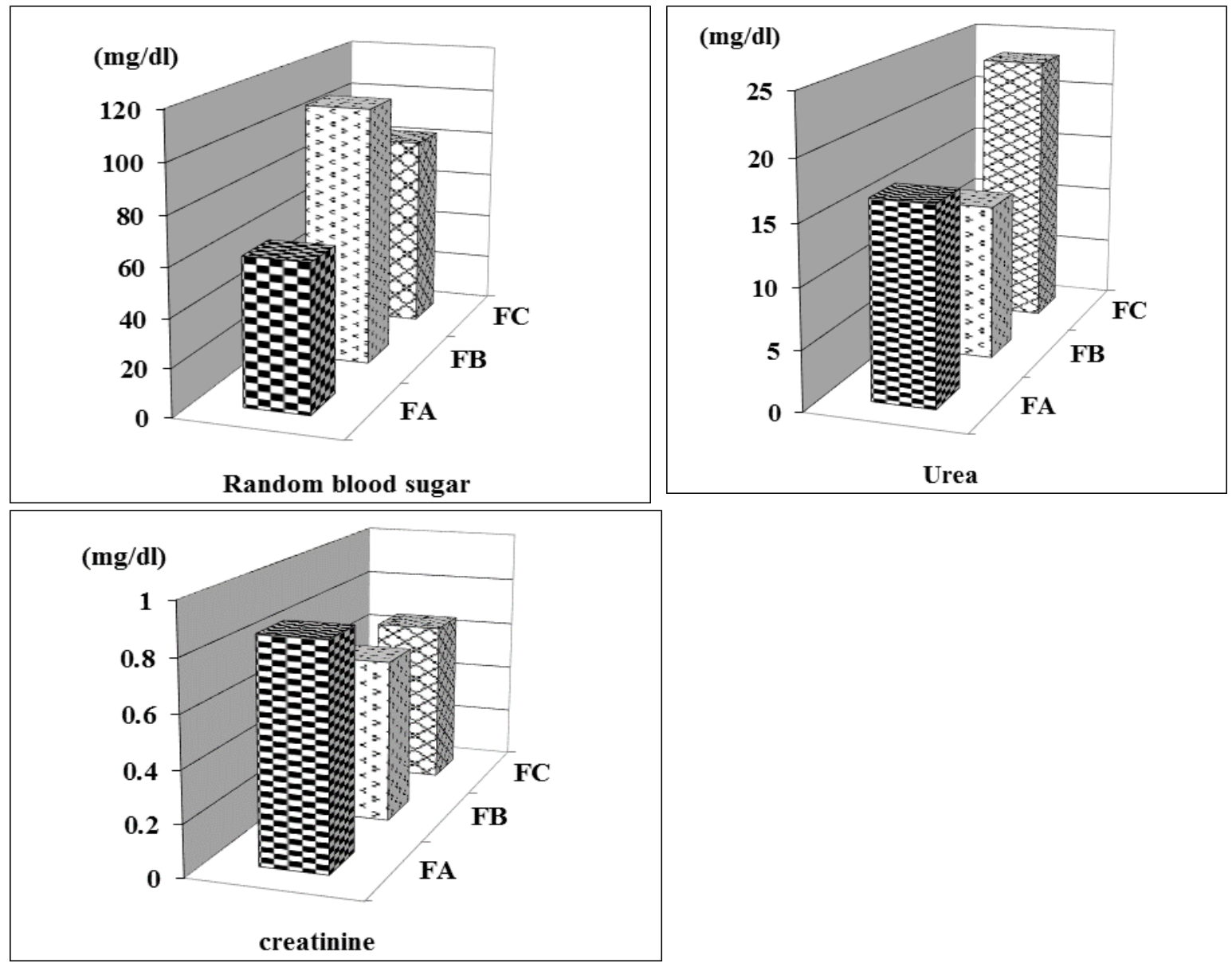

FA:-El- Gilani farm.

FB:-locanda farm

FC:-EL-Bats farm

Fig. (2). Biochemical levels in blood of Nile tilapia fish from three different fish farms. 


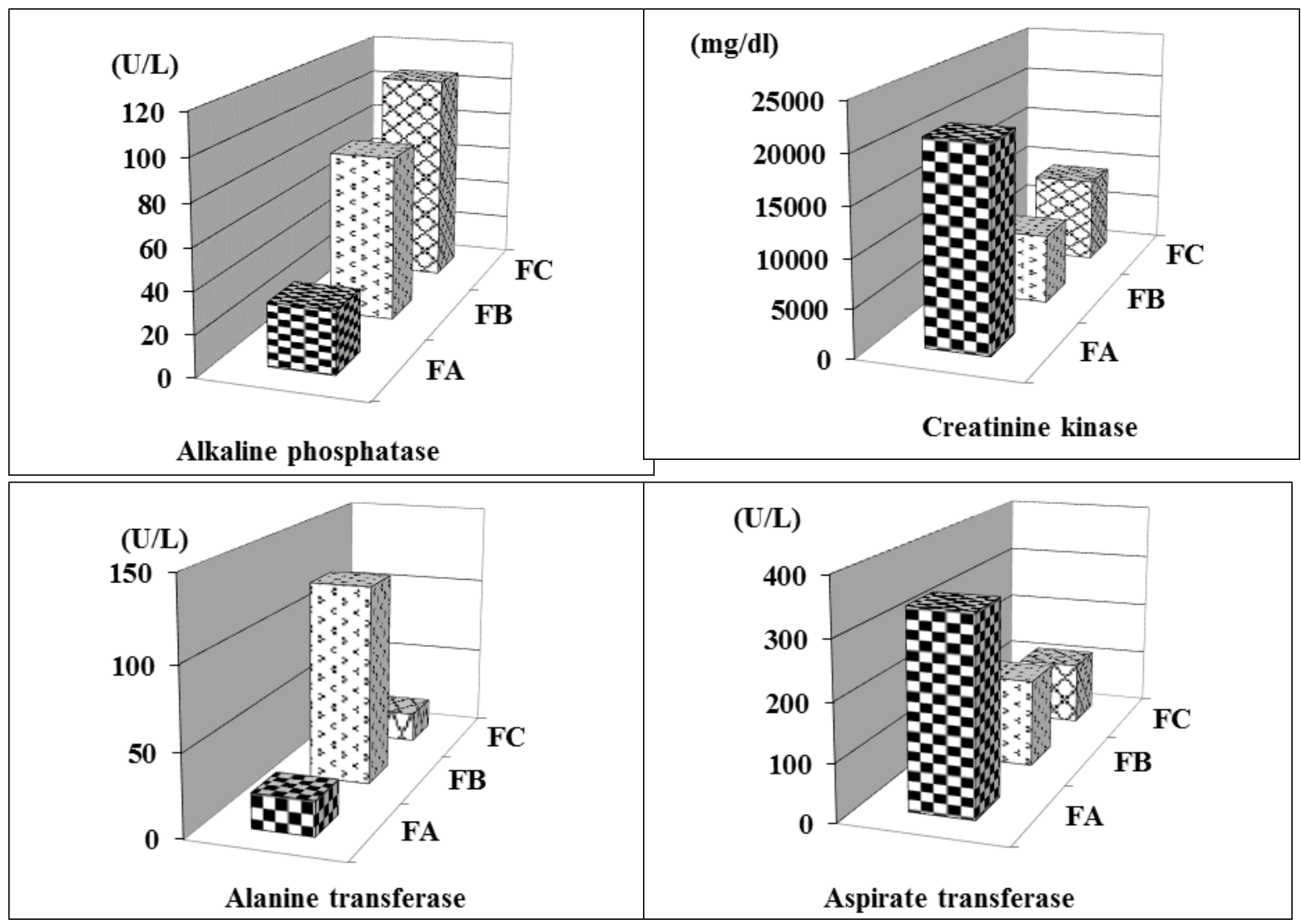

FA:-El- Gilani farm.

FB:-locanda farm

FC:-EL-Bats farm

Fig. (3). Enzymes level in blood of Nile tilapia fish from three different fish farms.

Variation in values of biochemical parameters levels at Fig. (2) indicated disrupted carbohydrates breakdown metabolism that result from the increase in Random blood sugar. This may be due to promote breakdown of liver and muscle glycogen via glycogenesis mediated perhaps by adrenocortical and catecholamine hormones and also reduction of insulin secretion, Gad (1999). The increase in the studied enzymes activities may be attributed to the damage in the liver tissues, liver enzyme inhibition by the action of the recorded bio accumulated heavy metals and pesticides and/or disturbance in Kreb's cycle as reported by Sanchez et al., (2005).

\section{CONCLUSION}

The present study concerned with the effect of residual pollutant on the fish farms by the examination of the concentration of different heavy metals in water, sediment, and fish blood collected from three different fish farms. The Nile tilapia was used as a biomarker of pollution with heavy metals by detecting their accumulation in blood. This work studies the influence of heavy metal on fish biochemistry by detecting glucose, liver and kidney functions and also the effect of metals on some blood enzyme activity. All the 
results emphasis that contamination of heavy metals such as zinc, iron, copper, lead, and cadmium in water fish farms is very hazards to aquatic life and for fish culture.

\section{REFERENCES}

Abubakar, U. M. (2012). Physico-chemical parameters in relation to fish production of DadinKowa Dam, Gombe State, Nigeria

Adhikari S.; Sarkar B.; Chatterjee A.; Mahapatra, C. T. and Ayyappan S. (2004). Effects of cypermethrin and carbofuran on certain hematological parameters and prediction of their recovery in a freshwater teleost, Labeorohita (Hamilton). Ecotoxicol. Environ. Safety.58 (2): 220-226.

Ahmed, M.H. and Elaa, A. A. (2003). Study of molluscan shells and their enclosed bottom sediments in the Manzala lagoon, Nile delta, Egypt. Bull Nat. Inst. of Oceanog. \& Fish. A.R.E., 29: 427-450.

APHA (1998). Standard Methods for the Examination of Water and Wastewaters. 20th ed. American Public Health Association, Washington D.D., USA.

Begüm, A.; Amin, M. D. N.; Kaneco, S. and Ohta, K. (2005). Selected elemental composition of the muscle tissue of three species of fish, Tilapia nilotica, Cirrhinamrigala and Clariusbatrachus, from the fresh water Dhanmondi Lake in Bangladesh. Food Chemistry, 93: 439-443.-

Beyer, V. O. and Vermeulen, N. P. E. (2003). Fish bioaccumulation and biomarkers in environmental risk assessment: a review. Environ. Toxicol. Pharmacol., 13: 57-149.

Boyd, C.E. and Tucker, C. S. (1979). Emergency aeration of fish ponds. Trans. Am. Fish. Soc., 108: 299-306.

Coldebella, A.; Gentelini, A.; Piana, P. A.; Coldebella, P. F; Boscolo, W. R. and Gad, N. S. (1999). Bioassay studies for assessment of the effect of some pesticides on tilpia zillii living in fresh and saline water Ph.D. thesis Fac. Sci., Ain shams university.

Collins, M. T. 1975). The effect of nitrite on the short term growth and survival of channel catfish, Letaruruspunctatus. Aquaculture, 24, 111-222.

Cripps, S. J. and Bergheim, A. (2000). Solids management and removal for intensive land-based aquaculture production systems. Aquaculture Engineering 22 33-56.

Egyptian Drinking Water Quality Standards (2007). Ministry of health population decision no (458).

Ehiagbonare, J. E. and Ogundiran, Y. O. (2010). Physico-chemical analysis of fish pond waters in Okada and its environs, Nigeria. African J. Biotech., 9(36), 59225928.

German clinical chemistry society (1977). Reference procedures for the determination of creatine kinase activity. Clin. Chem. Clin. Biochem., 15: 249 - 54.

Ghannam, H. E.; Talab, A. S.; Gaber, S. E. and Jahin, H. S. (2014). Assessment of heavy metals distribution in some freshwater fish organs using inductively coupled plasma optical emission spectrometry (ICP-OES). Ecology, Environment and Conservation Journal, 20 (2): 63-74.

Ghannam, H. E. (2021). Risk assessment of pollution with heavy metals in water and fish from River Nile, Egypt. App. Water Sci., 115-125. 
Kouadia, L. and Trefry, J. H. (1987). Saline trace metal contamination in the Ivory Coast West Africa. Air, Water and Soil Pollution. 32: 145 - 154.

Osredkar, J. and Sustar, N. (2011). Copper and zinc, biological role and significance of copper/zinc imbalance, J. Clin. Toxicol., 1-18.

Rashed, M. N. (2001). Monitoring of environmental heavy metals in fish from Nasser Lake, Environment International, 27: 27-33.

Sanchez, W.; Palluel, O.; Meunier, L.; Coquery, M.; Porcher, J. M. and Ait-Aissa S. (2005). Copper-induced oxidative stress in three-spined stickleback: relationship with hepatic metal levels. Environ. Toxicol. Pharmacol., 19: 171-183.

Sharma, K.; Shvetambri, K.; Verma, P. and Sharma, S. P. (2009) Physicochemical assessment of three freshwater ponds of Jammu (J\&K), Curr. World Environ., 4(2): 367-373.

SPSS (2008). Statistical Package for Social Science (for Windows). Release 17 Copyright (C), SPSS Inc., Chicago, USA.

Stanley, E. H.; Johnson, M. D. and Ward, A. K. (2003). Evaluating the influence of macrophytes on algal and bacterial production in multiple habitats of a freshwater wetland. American Society of Limnology and Oceanography, Inc. Limnol. Oceanogr 48(3): 1101-1111.

Stevens, R. (2009). Fish Pond Water Quality: As Simple as Chemistry 101, 37 (10), 8-9.

Talab, A. S.; Goher M. E.; Ghannam H. E. and Abdo, M. H. (2016). Chemical compositions and heavy metal contents of Oreochromis niloticus from the main irrigated canals (rayahs) of Nile Delta. Egyptian Journal of Aquatic Research, 42, 23-31.

Tietz, N. W.; Rinker A. D. and Shaw, L. M. (1983). Methods for the measurement of catalytic concentration of enzymes. Part 5. IFCC method for alkaline phosphatase. J. Clin. Chem. Clin. Biochem., 21:731-748.

Trinder, P. (1969). Determination of glucose in blood using glucose oxidase with an alternative oxygen receptor, Ann. Clin. Biochem., 6:24-27.

Warren, L.A. and Zimmerman, A.P. (1994) Suspended particulate oxides and organic matter interactions in trace metal sorption reactions in a small Urban River. Biogeochemistry 23:21-34.

WHO (2011). World health organization evaluation of certain food additive and contaminants: seventy-third report of the joint FAO/ WHO expert committee on food additives, WHO technical report series 9860, WHO 2011.

Yirgu, Z. (2011). Accumulation of Certain Heavy Metals in Nile Tilapia (Oreochromis nilotica) Fish Species Relative to Heavy Metal Concentration in Water of Lake Hawassa. A thesis Submitted for the degree of Masters of Science in Environmental Science, Addis Ababa University.

Zaghloul, K. H. (2008). ECO-Toxicological recovery of agricultural drainage water impact on Clarias gariepinus in EL-Fayoum Governorate, Egypt. J. Exp. Biol. (Zool.), 4: 73-79. 